\title{
STEROIDAL GLYCOSIDES FROM THE ROOTS OF SOLANUM MELONGENA L.
}

\author{
Stepan Shvets ${ }^{\mathrm{a}}$, Irina Nedova ${ }^{\mathrm{a} *}$, Pavel Kintia ${ }^{\mathrm{a}}$, Carla Bassarello ${ }^{\mathrm{b}}$, \\ Cosimo Pizza ${ }^{b}$ and Sonia Piacente ${ }^{\mathrm{b}}$ \\ Institute of Genetics and Physiology of Plants, Academy of Sciences of Moldova, \\ Padurii 20, 2002, Chisinau, Moldova \\ Dipartimento di Scienze Farmaceutiche, Università degli Studi di Salerno, \\ Via Ponte Don Melillo, 84084 Fisciano, Salerno, Italy \\ *lunga_irina@yahoo.com,tel. 37322 555259,fax 37322556180
}

\begin{abstract}
One new cholestane glycoside, six steroidal glycosides of spirostane series and one pregnane glycoside have been isolated from the roots of Solanum melongena L. (Solanaceae). Their structures were determined on the basis of chemical evidence and extensive spectroscopic methods including one-, two-dimensional NMR and MS analysis. In the roots of this plant the given compounds have been found out for the first time.
\end{abstract}

Keywords: steroidal glycoside, NMR analysis, Solanum melongena $L$.

\section{Introduction}

The Solanaceae family is a rich source of active secondary metabolites. In particular, the genus Solanum produces a great variety of steroidal saponins and glycoalkaloids of importance in the natural resistance of these plants against several pests [1]. Eggplant is distributed in southeast Asia, probably India and it is cultivated as a food crop in all warm areas of the world [2]. The fruit is hypotensive and helps to lower blood cholesterol levels and is suitable as part of a diet to help regulate high blood pressure [3].

The frequently observed antiviral [4], fungitoxic [5], cytostatic [6] and hypocholesterolemic [7] activities of the steroidal glycosides have aroused for years an interest of plant biochemists and physiologists. As it was reported earlier, Solanum melongena L. contains steroidal glycosides, so-called melongosides, which occur mainly in mature seeds $[8,9]$. Our interest in the chemical constituents elaborated by plants of Solanaceae family prompted us to take up the phytochemical investigation of the roots of Solanum melongena $L$. and report the isolation and structural elucidation of steroidal glycosides.

\section{Results and Discussion}

The water extract of roots of Solanum melongena L. was successively subjected to silica gel column chromatography, as well as HPLC to afford eight steroidal glycosides (1-8). All compounds have been isolated as amorphous powders. Their structures were determined by corresponding shifts of ${ }^{1} \mathrm{H}$ and ${ }^{13} \mathrm{C}$ NMR spectral data.

The ${ }^{1} \mathrm{H}$ NMR spectrum of 1 showed signals for four steroidal methyl groups at $\delta 1.16(3 \mathrm{H}, \mathrm{s}, \mathrm{Me}-19), 0.84$ $(3 \mathrm{H}, \mathrm{s}, \mathrm{Me}-18), 0.87(3 \mathrm{H}, \mathrm{d}, \mathrm{H}-21), 0.77(3 \mathrm{H}, \mathrm{d}, \mathrm{Me}-27)$, two methine proton signals at $\delta 3.62(1 \mathrm{H}, \mathrm{m}, \mathrm{H}-3)$ and 3.94 $(1 \mathrm{H}, \mathrm{m}, \mathrm{H}-16)$ indicative of secondary alcoholic functions and one double bond $\delta 5.41$ (broad, d, 1H-6), two methylene proton signals at $\delta 3.43(1 \mathrm{H}, \mathrm{m}, \mathrm{H}-26 \mathrm{a})$ and $3.37(1 \mathrm{H}, \mathrm{m}, \mathrm{H}-26 \mathrm{~b})$, ascribable to a primary alcoholic function, and signals for two anomeric protons at $\delta 4.43(1 \mathrm{H}, \mathrm{d}, J=7.5 \mathrm{~Hz})$ and $4.88(1 \mathrm{H}, \mathrm{d}, J=7.5 \mathrm{~Hz})$. The ${ }^{13} \mathrm{C}$ NMR spectrum displayed four methyl groups at 12.2, 13.6, 16.7 and 16.8, two oxygenbearing methine carbon at 76.8 (C-16) and 79.8 (C-3), one carbonyl group at 218.6 (C-22), three quaternary carbons at 36.4 (C-10), 45.5 (C-13) and 140.2 (C-5), seven methine carbons at 33.8 (C-25), 36.1 (C-8), 49.9 (C-20), 54.5 (C-14), 55.6 (C-9) and 63.9 (C-17), 122.6 (C-6), and ten methylene carbons at $\delta 21.9,28.3,30.2,31.9,35.1,38.2,39.6,41.1,54.5$ and 67.8. The HMBC disclosed the connectivities of the above functional carbons to form a cholestane skeleton. The C-25 configuration was deduced to be $R$ based on the difference of chemical shifts $\left(\Delta_{\mathrm{ab}}=\delta_{\mathrm{a}}-\delta_{\mathrm{b}}\right)$ of the geminal protons at $\mathrm{H}_{2}-26$ $\left(\Delta_{\mathrm{ab}}=0.06 \mathrm{ppm}\right)$. It has been described that $\Delta_{\mathrm{ab}}$ is usually $>0.57 \mathrm{ppm}$ in $25 S$ compounds and $<0.48$ in $25 R$ compounds [10]. It was evident from the combination of 1D-TOCSY and DQF-COSY spectral analysis that the sugar moiety have been consisted of glucose and rhamnose. A glycosidation shift was observed for C- $4_{\text {glc }}(\delta 79.5)$. The HMBC spectrum showed key correlation peaks between the proton signal at $\delta 4.43\left(\mathrm{H}-1_{\mathrm{glc}}\right)$ and the carbon resonance at $\delta 79.8$ (C-3 of the aglycon), the proton signal at $\delta 4.88\left(\mathrm{H}-1_{\text {rha }}\right)$ and the carbon resonance at $\delta 79.5$ $\left(\mathrm{C}-4_{\text {glc }}\right)$. Thus, the structure of compound 1 was deduced as $3-\mathrm{O}-\alpha-\mathrm{L}-$-rhamnopyranosyl- $(1 \rightarrow 4)-\beta$-D-

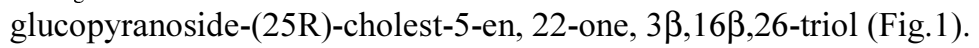


<smiles>[R9]C1CCC2(C)C(=CCC3C2CCC2(C)C3CC(O)[C@@H]2C(C)[C@@H](C)C(=O)CCCO)C1</smiles>

Fig. 1: $R=$ Rha(1-4)Glc

\begin{tabular}{|c|c|c|c|c|c|c|c|}
\hline \multicolumn{8}{|c|}{ Table. ${ }^{13} \mathrm{C}$ NMR spectral data $\left(300 \mathrm{MHz}, \mathrm{CD}_{3} \mathrm{OD}\right)$ of saponins (1-8) } \\
\hline carbon & & & con & & & & \\
\hline 1 & 2 & 3 & 4 & 5 & 6 & 7 & 8 \\
\hline 38.2 & 38.2 & 38.0 & 38.2 & 38.0 & 38.3 & 37.9 & 37.9 \\
\hline 30.2 & 32.5 & 30.6 & 32.5 & 30.6 & 32.6 & 30.4 & 30.1 \\
\hline 79.8 & 79.7 & 78.3 & 79.7 & 78.3 & 79.4 & 79.0 & 79.1 \\
\hline 35.1 & 39.4 & 34.9 & 39.4 & 34.9 & 40.9 & 34.9 & 39.0 \\
\hline 140.2 & 140.4 & 46.2 & 140.4 & 46.2 & 141.8 & 45.8 & 141.3 \\
\hline 122.6 & 122.7 & 32.9 & 122.7 & 32.9 & 122.8 & 32.9 & 121.5 \\
\hline 31.9 & 32.6 & 40.8 & 32.6 & 40.8 & 32.6 & 34.6 & 31.8 \\
\hline 36.1 & 31.2 & 36.6 & 31.2 & 36.6 & 31.2 & 36.0 & 30.4 \\
\hline 55.6 & 51.4 & 55.6 & 51.4 & 55.6 & 51.6 & 55.2 & 50.8 \\
\hline 36.4 & 37.4 & 36.8 & 37.4 & 36.8 & 37.8 & 36.5 & 37.2 \\
\hline 21.9 & 21.6 & 21.6 & 21.6 & 21.6 & 21.4 & 31.0 & 20.9 \\
\hline 41.1 & 40.6 & 40.9 & 40.6 & 40.9 & 40.7 & 40.5 & 35.1 \\
\hline 45.5 & 41.2 & 41.2 & 41.2 & 41.2 & 41.4 & 41.8 & 47.2 \\
\hline 54.5 & 57.5 & 57.7 & 57.5 & 57.7 & 57.6 & 57.5 & 57.3 \\
\hline 54.5 & 32.2 & 32.4 & 32.2 & 32.4 & 32.5 & 32.3 & 32.9 \\
\hline 76.8 & 82.1 & 82.0 & 82.1 & 82.0 & 82.3 & 82.1 & 147.0 \\
\hline 63.9 & 63.7 & 63.7 & 63.7 & 63.7 & 63.4 & 63.7 & 156.0 \\
\hline 13.6 & 16.4 & 16.6 & 16.4 & 16.6 & 16.9 & 16.7 & 15.7 \\
\hline 12.2 & 19.4 & 12.8 & 19.4 & 12.8 & 19.5 & 12.5 & 12.3 \\
\hline 49.9 & 42.6 & 43.1 & 42.6 & 43.1 & 42.8 & 42.6 & 199.3 \\
\hline 16.8 & 14.5 & 14.3 & 14.5 & 14.3 & 14.4 & 14.2 & 26.8 \\
\hline 218.6 & 109.0 & 110.5 & 109.0 & 110.5 & 110.7 & 110.5 & \\
\hline 39.6 & 30.2 & 32.5 & 30.2 & 32.5 & 32.5 & 32.2 & \\
\hline 28.3 & 29.5 & 29.5 & 29.5 & 29.5 & 29.7 & 29.1 & \\
\hline 33.8 & 32.8 & 31.1 & 32.8 & 31.1 & 31.1 & 31.2 & \\
\hline 76.2 & 67.5 & 67.7 & 67.5 & 67.7 & 67.8 & 67.7 & \\
\hline 16.7 & 17.2 & 16.6 & 17.2 & 16.6 & 16.9 & 16.7 & \\
\hline 102.0 & 102.0 & 102.0 & 100.1 & 100.1 & 100.5 & 100.5 & 102.0 \\
\hline 74.9 & 74.9 & 74.9 & 78.9 & 78.9 & 79.5 & 79.5 & 74.9 \\
\hline 76.6 & 76.6 & 76.6 & 79.2 & 79.2 & 78.4 & 78.4 & 76.6 \\
\hline 79.5 & 80.0 & 80.0 & 71.5 & 71.5 & 80.0 & 80.0 & 79.5 \\
\hline 76.4 & 76.5 & 76.5 & 77.5 & 77.5 & 76.6 & 76.6 & 76.4 \\
\hline 61.7 & 61.5 & 61.5 & 61.8 & 61.8 & 61.8 & 61.8 & 61.7 \\
\hline 102.5 & 102.5 & 102.5 & 101.9 & 101.9 & 103.2 & 103.2 & 102.5 \\
\hline 72.1 & 72.2 & 72.2 & 71.8 & 71.8 & 72.5 & 72.5 & 72.1 \\
\hline 71.9 & 72.0 & 72.0 & 72.2 & 72.2 & 72.4 & 72.4 & 71.9 \\
\hline 73.5 & 68.9 & 68.9 & 73.5 & 73.5 & 73.8 & 73.8 & 73.5 \\
\hline 70.3 & 70.2 & 70.2 & 69.5 & 69.5 & 70.9 & 70.9 & 70.3 \\
\hline 17.6 & 17.3 & 17.3 & 17.6 & 17.6 & 15.9 & 15.9 & 17.6 \\
\hline & & & & & 102.5 & 102.5 & \\
\hline & & & & & 72.3 & 72.3 & \\
\hline & & & & & 72.5 & 72.5 & \\
\hline & & & & & 73.8 & 73.8 & \\
\hline & & & & & 69.8 & 69.8 & \\
\hline & & & & & 15.8 & 15.8 & \\
\hline
\end{tabular}


The ${ }^{1} \mathrm{H}$ NMR spectrum of 2 showed signals for four steroidal methyl groups at $\delta 1.03$ (3H, s, Me-19), 0.85 $(3 \mathrm{H}, \mathrm{s}, \mathrm{Me}-18), 0.99(3 \mathrm{H}, \mathrm{d}, \mathrm{H}-21), 0.82(3 \mathrm{H}, \mathrm{d}, \mathrm{Me}-27)$, two methine proton signals at $\delta 3.62(1 \mathrm{H}, \mathrm{m}, \mathrm{H}-3)$ and 4.44 $(1 \mathrm{H}, \mathrm{m}, \mathrm{H}-16)$ indicative of secondary alcoholic functions and one double bond $\delta 5.42$ (broad d, 1H-6), two methylene proton signals at $\delta 3.35(1 \mathrm{H}, \mathrm{m}, \mathrm{H}-26 \mathrm{~b})$ and $3.47(1 \mathrm{H}, \mathrm{m}, \mathrm{H}-26 \mathrm{a})$, ascribable to a primary alcoholic function, and signals for two anomeric protons at $\delta 4.43(1 \mathrm{H}, \mathrm{d}, J=7.5 \mathrm{~Hz})$ and $4.88(1 \mathrm{H}, \mathrm{d}, J=7.5 \mathrm{~Hz})$. On the basis of the HSQC and HMBC correlations, the aglycone moiety of compound 2 was identified as $(25 R)$-spirost-5-ene-3 $\beta$ ol - diosgenin. Using a combination of 1D-TOCSY and DQF-COSY spectral analysis, the sugar moiety have been identified as glucose and rhamnose. A glycosidation shift was observed for $\mathrm{C}-4_{\mathrm{glc}}(\delta 80.0)$. The HMBC spectrum showed key correlation peaks between the proton signal at $\delta 4.43\left(\mathrm{H}-1_{\mathrm{glc}}\right)$ and the carbon resonance at $\delta 79.7(\mathrm{C}-3$ of the aglycon), the proton signal at $\delta 4.88\left(\mathrm{H}-1_{\text {rha }}\right)$ and the carbon resonance at $\delta 80.0\left(\mathrm{C}-4_{\mathrm{glc}}\right)$. Thus, the structure of compound 2 was deduced as (25R)-spirost-5-ene-3 $\beta$-ol - $3-O-\alpha-\mathrm{L}$ - rhamnopyranosyl - $(1 \rightarrow 4)$ - $\beta$ - Dglucopyranoside (Fig.2). Compound 2 has been previously reported in literature [11].

The ${ }^{1} \mathrm{H}$ NMR spectrum of 3 showed signals for four steroidal methyl groups at $\delta 0.89$ (3H, s, Me-19), 0.84 $(3 \mathrm{H}, \mathrm{s}, \mathrm{Me}-18), 1.02(3 \mathrm{H}, \mathrm{d}, \mathrm{H}-21), 0.98(3 \mathrm{H}, \mathrm{d}, \mathrm{Me}-27)$, two methine proton signals at $\delta 3.68(1 \mathrm{H}, \mathrm{m}, \mathrm{H}-3)$ and 4.39 $(1 \mathrm{H}, \mathrm{m}, \mathrm{H}-16)$ indicative of secondary alcoholic functions, two methylene proton signals at $\delta 3.29(1 \mathrm{H}, \mathrm{m}, \mathrm{H}-26 \mathrm{~b})$ and $3.41(1 \mathrm{H}, \mathrm{m}, \mathrm{H}-26 \mathrm{a})$, ascribable to a primary alcoholic function, and signals for two anomeric protons at $\delta 4.52$ $(1 \mathrm{H}, \mathrm{d}, J=7.5 \mathrm{~Hz})$ and $5.21(1 \mathrm{H}, \mathrm{d}, J=7.5 \mathrm{~Hz})$. On the basis of the HSQC and HMBC correlations, the aglycone

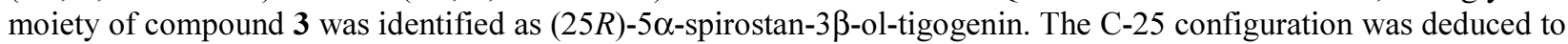
be $R$ based on the difference of chemical shifts $\left(\Delta_{\mathrm{ab}}=\delta_{\mathrm{a}}-\delta_{\mathrm{b}}\right)$ of the geminal protons at $\mathrm{H}_{2}-26\left(\Delta_{\mathrm{ab}}=0.12 \mathrm{ppm}\right) .5 \alpha$ configuration was deduced by HMBC correlation between the methyl signal at $\delta 0.89$ (Me-19) and carbon resonances at $\delta 55.6(\mathrm{C}-9), 46.2(\mathrm{C}-5)$ and $38.0(\mathrm{C}-1)$. Using a combination of 1D-TOCSY and DQF-COSY spectral analysis, the sugar moiety have been identified as glucose and rhamnose. A glycosidation shift was observed for $\mathrm{C}-4_{\text {glc }}(\delta 80.0)$. The HMBC spectrum showed key correlation peaks between the proton signal at $\delta 4.43\left(\mathrm{H}-1_{\text {glc }}\right)$ and the carbon resonance at $\delta 78.3\left(\mathrm{C}-3\right.$ of the aglycon), the proton signal at $\delta 4.88\left(\mathrm{H}-1_{\text {rha }}\right)$ and the carbon resonance at $\delta 80.0\left(\mathrm{C}-4_{\mathrm{glc}}\right)$. Thus, the structure of compound 3 was deduced as $(25 R)-5 \alpha-$ spirostan $-3 \beta-\mathrm{ol}-3-O-\alpha-\mathrm{L}-$ rhamnopyranosyl-(1 $\rightarrow 4$ ) - $\beta$ - D-glucopyranoside (Fig.2). Compound $\mathbf{3}$ has been previously reported in literature [12].

Compound 4 , in the positive ESIMS, showed a major ion peak at $m / z 723[\mathrm{M}+\mathrm{Na}]^{+}$and significant fragments at $m / z 579[\mathrm{M}+\mathrm{Na}-146]^{+}$attributable to the loss of a pentose unit. The molecular formula of $\mathbf{4}$ was unequivocally established to be $\mathrm{C}_{39} \mathrm{H}_{62} \mathrm{O}_{12}$ by HR-MALDI-MS $\left(\mathrm{m} / z\right.$ 725.392 $\left.[\mathrm{M}+\mathrm{Na}]^{+}\right)$. The ${ }^{1} \mathrm{H}$ NMR spectrum of 4 showed signals for four steroidal methyl groups at $\delta 0.85(\mathrm{~s}, 3 \mathrm{H}-18), 0.82(\mathrm{~d}, 3 \mathrm{H}-27), 0.99(\mathrm{~d}, 3 \mathrm{H}-21)$ and $1.03(\mathrm{~s}, 3 \mathrm{H}-19)$, two methylene proton signals at $\delta 3.35(1 \mathrm{H}, \mathrm{dd}, \mathrm{H}-26 \mathrm{~b})$ and $3.47(1 \mathrm{H}, \mathrm{t}, \mathrm{H}-26 \mathrm{a})$ ascribable to a primary alcoholic functions, two methine proton signals at $\delta 3.62(1 \mathrm{H}, \mathrm{m}, \mathrm{H}-3)$ and $4.44(1 \mathrm{H}, \mathrm{m}, \mathrm{H}-16)$ indicative of secondary alcoholic function and one double bond $\delta 5.42$ (broad d, 1H-6). One primary alcoholic function at $\delta 67.5$ (C-26), suggesting the occurrence of a glycoside spirostanol skeleton. The HMBC correlation of methyl groups clearly showed that the aglycon moiety was similar of compound $\mathbf{2}$ and was identified as $(25 R)$-spirost-5-ene-3 $\beta$-ol. From 1D-TOCSY and DQF-COSY spectral analysis has been identified that the sugar moiety consists of glucose and rhamnose. The HMBC spectrum showed key correlation peaks between the proton signal at $\delta 4.51\left(\mathrm{H}-1_{\mathrm{glc}}\right)$ and the carbon resonance at $\delta 79.7$ (C-3 of the aglycon), the proton signal at $\delta 5.22\left(\mathrm{H}-1_{\mathrm{rha}}\right)$ and the carbon resonance at $\delta 78.9\left(\mathrm{C}-2_{\mathrm{glc}}\right)$. The structure of compound 4 was assigned as $(25 R)-$ spirost - 5- ene - $3 \beta-$ ol $-3-O-\alpha-\mathrm{L}-$ rhamnopyranosyl - (1 $\rightarrow 2)$ - $\beta$-D- glucopyranoside (Fig.2).

The ${ }^{1} \mathrm{H}$ NMR spectrum of 5 showed signals for four steroidal methyl groups at $\delta 0.89$ ( $\left.3 \mathrm{H}, \mathrm{s}, \mathrm{Me}-19\right), 0.82$ $(3 \mathrm{H}, \mathrm{s}, \mathrm{Me}-18), 1.00(3 \mathrm{H}, \mathrm{d}, \mathrm{H}-21), 1.12(3 \mathrm{H}, \mathrm{d}, \mathrm{Me}-27)$. The HMBC correlation of methyl groups clearly showed that the aglycon moiety was similar of compound 2 was identified as $(25 R)-5 \alpha$ - spirostan-3 $\beta$-ol. One primary alcoholic function at $\delta 67.7$ (C-26), suggesting the occurrence of a glycoside spirostanol skeleton. Using a combination of 1D-TOCSY and DQF-COSY spectral analysis, the sugar moiety have been determined to be identical with sugar moiety of compound 3 . The HMBC spectrum showed key correlation peaks between the proton signal at $\delta 4.51\left(\mathrm{H}-1_{\mathrm{glc}}\right)$ and the carbon resonance at $\delta 78.3(\mathrm{C}-3)$, the proton signal at $\delta 5.22\left(\mathrm{H}-1_{\text {rha }}\right)$ and the carbon resonance

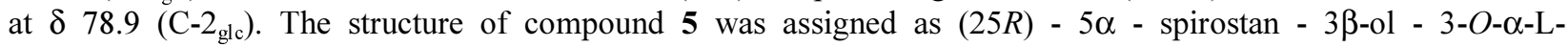
rhamnopyranosyl-(1 $\rightarrow 2)$ - $\beta$ - D-glucopyranoside (Fig.2). Compounds $\mathbf{4}$ and $\mathbf{5}$ has been previously isolated from Hyoscyamus niger L. [13].

The ${ }^{1} \mathrm{H}$ NMR spectrum of 6 showed signals for four steroidal methyl groups at $\delta 1.02(3 \mathrm{H}, \mathrm{s}, \mathrm{Me}-19), 0.83$ $(3 \mathrm{H}, \mathrm{s}, \mathrm{Me}-18), 0.98$ (3H, d, H-21), 0.83 (3H, d, Me-27). The HMBC correlation of methyl groups clearly showed that the aglycon moiety was similar of compounds $\mathbf{2}$ and $\mathbf{4}$ and was identified as diosgenin. The ${ }^{1} \mathrm{H}$ NMR spectrum showed signals for three anomeric protons at $\delta 4.53(1 \mathrm{H}, \mathrm{d}, J=7.5 \mathrm{~Hz}), 4.87(1 \mathrm{H}, \mathrm{d}, J=7.5 \mathrm{~Hz})$, and $5.23(1 \mathrm{H}, \mathrm{d}, J$ $=7.5 \mathrm{~Hz}$ ). It was evident from the ${ }^{1} \mathrm{H}$ and ${ }^{13} \mathrm{C}$ NMR data that the sugar chain at $\mathrm{C}-3$ of 6 consisted of three sugar units. The chemical shifts of all the individual protons of the three sugar units were ascertained from a combination of 1D-TOCSY and DQF-COSY spectral analysis, and the ${ }^{13} \mathrm{C}$ chemical shifts of their relative attached carbons could be assigned unambiguously from the HSQC spectrum. These data showed the presence of one $\beta$-glucopyranosyl unit 
( $\delta 4.53)$ and two $\alpha$-rhamnopyranosyl unit ( $\delta 4.87$ and 5.23). A glycosidation shifts were observed for $\mathrm{C}-2_{\mathrm{glc}}(\delta 79.5)$ and for $\mathrm{C}-4_{\mathrm{glc}}(\delta 80.0)$. The HMBC spectrum showed key correlation peaks between the proton signal at $\delta 4.53$ $\left(\mathrm{H}-1_{\mathrm{glc}}\right)$ and the carbon resonance at $\delta 79.4\left(\mathrm{C}-3\right.$ of the aglycon), the proton signal at $\delta 4.87\left(\mathrm{H}-1_{\mathrm{rha}}\right)$ and the carbon resonance at $\delta 79.5\left(\mathrm{C}-2_{\mathrm{glc}}\right)$, the proton signal at $\delta 5.23\left(\mathrm{H}-1_{\text {rhal }}\right)$ and the carbon resonance at $\delta 80.0\left(\mathrm{C}-4_{\mathrm{glc}}\right)$. Thus, the structure of compound $\mathbf{6}$ was deduced as $(25 R)$-spirost-5-ene-3 $\beta$-ol-3- $O$-[[ $\alpha$-L-rhamnopyranosyl- $(1 \rightarrow 2)]-\alpha-\mathrm{L}-$ rhamnopyranosyl-(1 $\rightarrow 4)-\beta$-D-glucopyranoside] (Fig.2), which has been previously isolated from Solanum plants [14].

The ${ }^{1} \mathrm{H}$ NMR spectrum of 7 showed signals for four steroidal methyl groups at $\delta 0.89(3 \mathrm{H}, \mathrm{s}, \mathrm{Me}-19), 0.82$ $(3 \mathrm{H}, \mathrm{s}, \mathrm{Me}-18), 1.00(3 \mathrm{H}, \mathrm{d}, \mathrm{H}-21), 1.12(3 \mathrm{H}, \mathrm{d}, \mathrm{Me}-27)$. The HMBC correlation of methyl groups clearly showed that the aglycon moiety was similar of compound 3 was identified as $(25 R)-5 \alpha$-spirostan-3 $\beta$-ol. One primary alcoholic function at $\delta 67.7$ (C-26), suggesting the occurrence of a glycoside spirostanol skeleton. The ${ }^{1} \mathrm{H}$ NMR spectrum showed signals for three anomeric protons at $\delta 4.39(1 \mathrm{H}, \mathrm{d}, J=7.5 \mathrm{~Hz}), 4.56(1 \mathrm{H}, \mathrm{d}, J=7.5 \mathrm{~Hz})$, and $4.69(1 \mathrm{H}, \mathrm{d}, J=7.5 \mathrm{~Hz})$. It was evident from the ${ }^{1} \mathrm{H}$ and ${ }^{13} \mathrm{C}$ NMR data that the sugar chain at $\mathrm{C}-3$ of 7 consisted of three sugar units. The sugar chain was similar to sugar chain of compound $\mathbf{6}$. A glycosidation shifts were observed for $\mathrm{C}-2_{\mathrm{glc}}(\delta 79.5)$ and for $\mathrm{C}-4_{\mathrm{glc}}(\delta 80.0)$. The HMBC spectrum showed key correlation peaks between the proton signal at $\delta 4.53\left(\mathrm{H}-1_{\mathrm{glc}}\right)$ and the carbon resonance at $\delta 79.0(\mathrm{C}-3)$, the proton signal at $\delta 4.87\left(\mathrm{H}-1_{\text {rha }}\right)$ and the carbon resonance at $\delta 79.5\left(\mathrm{C}-2_{\mathrm{glc}}\right)$, the proton signal at $\delta 5.23\left(\mathrm{H}-1_{\text {rhal }}\right)$ and the carbon resonance at $\delta 80.0\left(\mathrm{C}-4_{\mathrm{glc}}\right)$. The structure of compound 7 was assigned as $(25 R)-5 \alpha$-spirostan-3 $\beta$-ol-3- $O$-[[ $\alpha$-L-rhamnopyranosyl- $(1 \rightarrow 2)]-\alpha-\mathrm{L}-$ rhamnopyranosyl-(1 $\rightarrow 4)$ - $\beta$-D-glucopyranoside] (Fig.2), which has been previously isolated from the seeds of Solanum melongena L. [15].

${ }^{1} \mathrm{H}$ NMR spectrum of compound 8 displayed signals for three tertiary methyl groups at $0.95(3 \mathrm{H}, \mathrm{s}, \mathrm{Me}-19)$, $1.02(3 \mathrm{H}, \mathrm{s}, \mathrm{Me}-18)$ and $2.28(3 \mathrm{H}, \mathrm{s}, \mathrm{Me}-21)$, one double bond $\delta 5.42$ (broad d, 1H-6), one olefinic proton at 6.91 $(1 \mathrm{H}, \mathrm{m}, \mathrm{H}-16)$ together with two anomeric protons $(1 \mathrm{H}, \mathrm{d}, 4.43 ; 1 \mathrm{H}, \mathrm{d}, 4.88)$. On the other hand, the ${ }^{13} \mathrm{C}$ NMR signals due to a total of 21 carbon signals originating from the sapogenol were composed of three methyl groups at 12.3 (C-19), 15.7 (C-18), and 26.8 (C-21), one oxygenbearing methine carbon at 79.1 (C-3), one carbonyl group at 199.3 (C-20), two quaternary carbons at $37.2(\mathrm{C}-10)$ and 47.2 (C-13), three methine carbons at 30.4 (C-8), 50.8 (C-9) and 57.3 (C-14), seven methylene carbons at $\delta 20.9$ (C-11), 30.1 (C-2), 31.8 (C-7), 32.9 (C-15), 39.0 (C-4), 35.1 (C12 ), and $37.9(\mathrm{C}-1)$, and four olefinic carbons at $\delta 121.5(\mathrm{C}-6), 141.3(\mathrm{C}-5), 147.0(\mathrm{C}-16)$ and 156.0 (C-17). The HMBC disclosed the connectivities of the above functional carbons to form a pregnane skeleton. The NMR data of sugar moiety was identical of compound 2. HMBC spectrum showed key correlation picks between sugars anomeric protons and attached carbons at $4.43(\mathrm{H}-1 \mathrm{glc})$ and 79.1 (C-3 agl), 4.88 (H-1rha) and 79.5 (C-4glc). Thus, compound 8 was elucidated as 3-O- $\alpha$-L-rhamnopyranosyl - $(1 \rightarrow 4)-\beta$ - D - glucopyranoside - pregn - 5, 16 - dien - 20 - one, $3 \beta$-ol (Fig.2), earlier reported in literature [16].

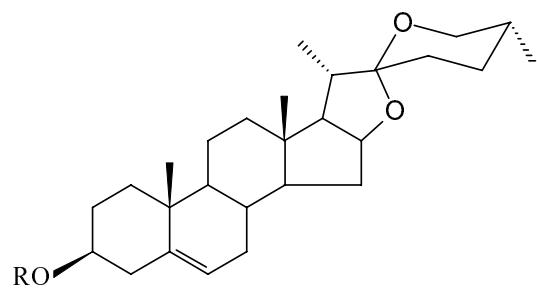

2: $\mathrm{R}=\mathrm{Rha}(1 \rightarrow 4) \mathrm{Glc}$

4: $\mathrm{R}=\mathrm{Rha}(1 \rightarrow 2) \mathrm{Glc}$

6: $\mathrm{R}=[\mathrm{Rha}(1 \rightarrow 4)] \mathrm{Rha}(1-2) \mathrm{Glc}$

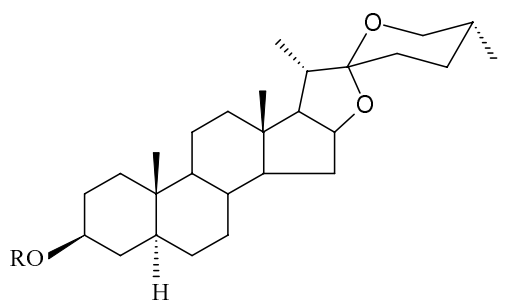

Fig. 2.

3: $\mathrm{R}=\mathrm{Rha}(1 \rightarrow 4) \mathrm{Glc}$

5: $\mathrm{R}=\mathrm{Rha}(1 \rightarrow 2) \mathrm{Glc}$

7: $\mathrm{R}=[\mathrm{Rha}(1 \rightarrow 4)] \mathrm{Rha}(1-2) \mathrm{Glc}$

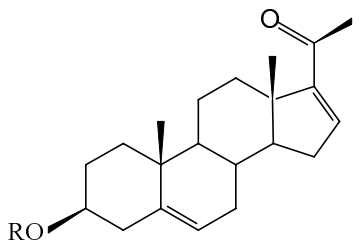

8: $\mathrm{R}=\mathrm{Rha}(1 \rightarrow 4) \mathrm{Glc}$

\section{Experimental}

Optical rotations were measured on a Jasco DIP 1000 polarimeter. Melting points were measured on the Boetius table. Exact masses were measured by a Voyager DE mass spectrometer (Applied Biosystems, Foster City, CA). Samples were analyzed by matrix assisted laser desorption ionization (MALDI) mass spectrometry. Mass calibration was performed with the ions from ACTH (fragment 18-39) at $2465.1989 \mathrm{Da}$ and Angiotensin III at 931.5154 Da as internal standards. ESI-MS analyses were performed using a ThermoFinnigan LCQ Deca XP Max ion trap mass spectrometer equipped with Xcalibur software. Samples were dissolved in MeOH (Baker) and infused in the ESI source by using a syringe pump. The capillary voltage was $43 \mathrm{~V}$, the spray voltage $5 \mathrm{kV}$, and the tube lens offset $30 \mathrm{~V}$. The capillary temperature was $280^{\circ} \mathrm{C}$. NMR experiments were performed at $300 \mathrm{~K}$ by dissolving each sample in $500 \mu \mathrm{L}$ of CD3OD (Carlo Erba, $99.8 \% \mathrm{D})\left({ }^{1} \mathrm{H}, \delta=3.34 \mathrm{ppm} ;{ }^{13} \mathrm{C}, \delta=49.0 \mathrm{ppm}\right.$ ) on a Bruker DRX-600 spectrometer equipped with a $5 \mathrm{~mm}$ TCI CryoProbe. All spectra were acquired in the phase sensitive mode and the TPPI method was used for quadrature detection in the $\omega 1$ dimension. HPLC separations were carried out on a Waters 590 system equipped with a Waters R401 refractive index detector and a Rheodyne injector. TLC was performed on silica gel plates (Merck precoated silica gel $60 \mathrm{~F}_{254}$ ). All solvents for chromatographic separation were of analytical 
grade from Carlo Erba (Rodano, Italy). HPLC grade water $(18 \mathrm{~m} \Omega)$ was prepared using a Millipore Milli-Q purification system (Millipore Corp., Bedford, MA).

Plant Material has been collected in the scientific research field of the Institute of Genetics and Plant Physiology in October 2003 year. The voucher specimen has been deposited in the Laboratory of Genetics and Physiology of Plant Stability.

The dried and powdered roots of Solanum melongena L. $(1000 \mathrm{~g})$ were extracted three times at $100^{\circ} \mathrm{C}$ with water for 4 hours. Water extracts were combined and extracted with n-butanol, after that n-butanol was evaporated under reduced pressure to give a mixture of saponins $(9,6 \mathrm{~g})$. This mixture have been chromatographied on silica gel

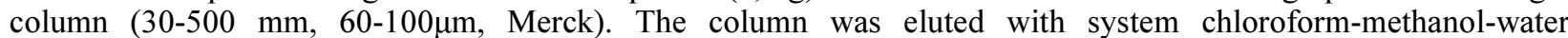
$(8: 2: 0 \rightarrow 20: 10: 1)$. After monitoring by TLC [Si gel plates, chloroform-methanol (85:15)] fractions showing identical characteristics were combined to give A $(120 \mathrm{mg}), \mathrm{B}(200 \mathrm{mg}), \mathrm{C}(175 \mathrm{mg}), \mathrm{D}(230)$ and E (105 mg). Fractions A-E were submitted to HPLC on a Waters XTerra Prep $C_{18}$ column $(300 \times 7.8 \mathrm{~mm}$ i.d., the flow rate was $2 \mu \mathrm{L} / \mathrm{min}$.), using a $\mathrm{MeOH}: \mathrm{H}_{2} \mathrm{O}$ in the ratio 85:15 for $\mathrm{A}-\mathrm{C}, 70: 30$ for $\mathrm{D}$ and 75:35 for $\mathrm{E}$ (isocratic conditions). Pure 8 (6 mg, $\mathrm{Rt}=18 \mathrm{~min})$ was obtained from $\mathrm{A}, 4(7 \mathrm{mg}, \mathrm{Rt}=11 \mathrm{~min}), \mathbf{5}(10 \mathrm{mg}, \mathrm{Rt}=19 \mathrm{~min})$ from $\mathrm{B}, 2(9 \mathrm{mg}, \mathrm{Rt}=9 \mathrm{~min}), 3$ $(11 \mathrm{mg}, \mathrm{Rt}=17 \mathrm{~min})$ from $\mathrm{C}, 6(8 \mathrm{mg}, \mathrm{Rt}=5 \mathrm{~min}), 7(11 \mathrm{mg}, \mathrm{Rt}=7 \mathrm{~min})$ from $\mathrm{D}$ and $1(7 \mathrm{mg}, \mathrm{Rt}=15 \mathrm{~min})$ from $\mathrm{E}$.

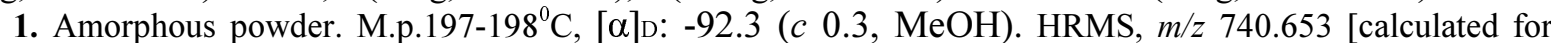
$\left.\mathrm{C}_{39} \mathrm{H}_{64} \mathrm{O}_{13}(\mathrm{M})^{+}\right] ; 594.5[\mathrm{M}-146]^{+} ;{ }^{1} \mathrm{H}$ NMR (aglycon) $\delta 3.94(1 \mathrm{H}, \mathrm{m}, \mathrm{H}-16), 3.62(1 \mathrm{H}, \mathrm{m}, \mathrm{H}-3), 3.43(1 \mathrm{H}, \mathrm{m}, \mathrm{H}-26 \mathrm{a})$, $3.37(1 \mathrm{H}, \mathrm{m}, \mathrm{H}-26 \mathrm{~b}), 1.16(3 \mathrm{H}, \mathrm{s}, \mathrm{Me}-19), 0.84$ (3H, s, Me-18), 0.87 (3H, d, H-21), 0.77 (3H, d, Me-27). (sugars) 4.43 (d, $J=7.5 \mathrm{~Hz}, \mathrm{H}-1 \mathrm{Glc}), 3.22$ (dd, $J=7.5$ and $9.0 \mathrm{~Hz}, \mathrm{H}-2 \mathrm{Glc}$ ), 3.49 (dd, $J=9.0$ and $9.0 \mathrm{~Hz}, \mathrm{H}-3 \mathrm{Glc}$ ), 3.56 (dd, $J=9.0$ and $9.0 \mathrm{~Hz}, \mathrm{H}-4 \mathrm{Glc}$ ), 3.35 (ddd, $J=2.5,4.5$ and $9.0 \mathrm{~Hz}, \mathrm{H}-5 \mathrm{Glc}$ ), 3.82 (dd, $J=4.5$ and 11.5 Hz, H-6a Glc), 3.69 (dd, $J=2.5$ and $11.5 \mathrm{~Hz}, \mathrm{H}-6 \mathrm{~b}$ Glc). 4.88 (d, H-1Rha), 3.87 (dd, H-2 Rha), 3.66 (dd, H-3 Rha), 3.43 (dd, H-4 Rha), 3.99 (m, H-5 Rha), 1.29 (d, H-6 Rha). For ${ }^{13} \mathrm{C}$ NMR see Table.

2. Amorphous powder. M.p.230-23 $1^{0} \mathrm{C}$, $[\alpha] \mathrm{D}$ : -89.0 (pyridine). HRMS, $m / z 722.345$ [calculated for $\mathrm{C}_{39} \mathrm{H}_{62} \mathrm{O}_{12}$ $\left.(\mathrm{M})^{+}\right]$; $576.7[\mathrm{M}-146]^{+} ;{ }^{1} \mathrm{H}$ NMR (aglycon) $\delta 4.44(1 \mathrm{H}, \mathrm{m}, \mathrm{H}-16), 3.62(1 \mathrm{H}, \mathrm{m}, \mathrm{H}-3), 3.47(1 \mathrm{H}, \mathrm{m}, \mathrm{H}-26 \mathrm{a}), 3.35(1 \mathrm{H}$ m, H-26b), 1.03 (3H, s, Me-19), 0.85 (3H, s, Me-18), 0.99 (3H, d, H-21), 0.82 (3H, d, Me-27). (sugars) 4.43 (d, $J=7.5 \mathrm{~Hz}, \mathrm{H}-1 \mathrm{Glc}$ ), 3.22 (dd, $J=7.5$ and $9.0 \mathrm{~Hz}, \mathrm{H}-2 \mathrm{Glc}$ ), 3.49 (dd, $J=9.0$ and $9.0 \mathrm{~Hz}, \mathrm{H}-3 \mathrm{Glc}$ ), 3.56 (dd, $J=9.0$ and $9.0 \mathrm{~Hz}, \mathrm{H}-4 \mathrm{Glc}$ ), 3.35 (ddd, $J=2.5,4.5$ and $9.0 \mathrm{~Hz}, \mathrm{H}-5 \mathrm{Glc}$ ), 3.82 (dd, $J=4.5$ and $11.5 \mathrm{~Hz}, \mathrm{H}-6 \mathrm{a}$ Glc), 3.68 (dd, $J=2.5$ and $11.5 \mathrm{~Hz}, \mathrm{H}-6 \mathrm{~b}$ Glc). 4.88 (d, H-1Rha), 3.87 (dd, H-2 Rha), 3.66 (dd, H-3 Rha), 3.35 (dd, H-4 Rha), 4.00 (m, H-5 Rha), 1.29 (d, H-6 Rha). For ${ }^{13} \mathrm{C}$ NMR see Table.

3. Amorphous powder. M.p. $233^{\circ} \mathrm{C},[\alpha] \mathrm{D}$ : $-69.0(\mathrm{MeOH})$. HRMS, $m / z 725.321$ [calculated for $\mathrm{C}_{39} \mathrm{H}_{64} \mathrm{O}_{12}$ $\left.(\mathrm{M})^{+}\right]$; $579.7[\mathrm{M}-146]^{+} ;{ }^{1} \mathrm{H}$ NMR (aglycon) $\delta 4.39(1 \mathrm{H}, \mathrm{m}, \mathrm{H}-16), 3.68(1 \mathrm{H}, \mathrm{m}, \mathrm{H}-3), 3.41(1 \mathrm{H}, \mathrm{m}, \mathrm{H}-26 \mathrm{a}), 3.29(1 \mathrm{H}$, m, H-26b), 0.89 (3H, s, Me-19), 0.84 (3H, s, Me-18), 1.02 (3H, d, H-21), 0.98 (3H, d, Me-27). (sugars) 4.43 (d, $J=7.5 \mathrm{~Hz}, \mathrm{H}-1 \mathrm{Glc}$ ), 3.22 (dd, $J=7.5$ and $9.0 \mathrm{~Hz}, \mathrm{H}-2 \mathrm{Glc}$ ), 3.49 (dd, $J=9.0$ and $9.0 \mathrm{~Hz}, \mathrm{H}-3 \mathrm{Glc}$ ), 3.56 (dd, $J=9.0$ and $9.0 \mathrm{~Hz}, \mathrm{H}-4 \mathrm{Glc}$ ), 3.35 (ddd, $J=2.5,4.5$ and $9.0 \mathrm{~Hz}, \mathrm{H}-5 \mathrm{Glc}$ ), 3.82 (dd, $J=4.5$ and $11.5 \mathrm{~Hz}, \mathrm{H}-6 \mathrm{a} \mathrm{Glc}$ ), 3.68 (dd, $J=2.5$ and $11.5 \mathrm{~Hz}, \mathrm{H}-6 \mathrm{~b}$ Glc). 4.88 (d, H-1Rha), 3.87 (dd, H-2 Rha), 3.66 (dd, H-3 Rha), 3.35 (dd, H-4 Rha), 4.00 (m, H-5 Rha), 1.29 (d, H-6 Rha). For ${ }^{13} \mathrm{C}$ NMR see Table.

4. Amorphous powder. M.p.238-240 ${ }^{\circ}$ C, [ $\alpha$ ]D: -99.0 (pyridine). HRMS, $m / z 722.533$ [calculated for $\mathrm{C}_{39} \mathrm{H}_{62} \mathrm{O}_{12}$ $\left.(\mathrm{M})^{+}\right] ; 576.5[\mathrm{M}-146]^{+} ;{ }^{1} \mathrm{H}$ NMR (aglycon) $\delta 4.44(1 \mathrm{H}, \mathrm{m}, \mathrm{H}-16), 3.62(1 \mathrm{H}, \mathrm{m}, \mathrm{H}-3), 3.47(1 \mathrm{H}, \mathrm{m}, \mathrm{H}-26 \mathrm{a}), 3.35(1 \mathrm{H}$, m, H-26b), 1.03 (3H, s, Me-19), 0.85 (3H, s, Me-18), 0.99 (3H, d, H-21), 0.82 (3H, d, Me-27). (sugars) 4.51 (d, $J=7.5 \mathrm{~Hz}, \mathrm{H}-1 \mathrm{Glc}$ ), 3.38 (dd, $J=7.5$ and $9.0 \mathrm{~Hz}, \mathrm{H}-2 \mathrm{Glc}$ ), 3.49 (dd, $J=9.0$ and $9.0 \mathrm{~Hz}, \mathrm{H}-3 \mathrm{Glc}$ ), 3.28 (dd, $J=9.0$ and $9.0 \mathrm{~Hz}, \mathrm{H}-4 \mathrm{Glc}$ ), 3.26 (ddd, $J=2.5,4.5$ and $9.0 \mathrm{~Hz}, \mathrm{H}-5 \mathrm{Glc}$ ), 3.89 (dd, $J=4.5$ and $11.5 \mathrm{~Hz}, \mathrm{H}-6 \mathrm{a}$ Glc), 3.68 (dd, $J=2.5$ and $11.5 \mathrm{~Hz}, \mathrm{H}-6 \mathrm{~b}$ Glc). 5.22 (d, H-1 Rha), 3.94 (dd, H-2 Rha), 3.69 (dd, H-3 Rha), 3.42 (dd, H-4 Rha), 4.16 (m, H-5 Rha), 1.27 (d, H-6 Rha). For ${ }^{13} \mathrm{C}$ NMR see Table.

5. Amorphous powder. M.p.241-242 ${ }^{0} \mathrm{C}$, $[\alpha] \mathrm{D}:-56.0$ (MeOH). HRMS, $m / z 725.451$ [calculated for $\mathrm{C}_{39} \mathrm{H}_{64} \mathrm{O}_{12}$ $\left.(\mathrm{M})^{+}\right] ; 579.7[\mathrm{M}-146]^{+} ;{ }^{1} \mathrm{H}$ NMR (aglycon) $\delta 4.41(1 \mathrm{H}, \mathrm{m}, \mathrm{H}-16), 3.77(1 \mathrm{H}, \mathrm{m}, \mathrm{H}-3), 3.47(1 \mathrm{H}, \mathrm{m}, \mathrm{H}-26 \mathrm{a}), 3.34(1 \mathrm{H}$, m, H-26b), 0.89 (3H, s, Me-19), 0.82 (3H, s, Me-18), 1.00 (3H, d, H-21), 1.12 (3H, d, Me-27). (sugars) 4.51 (d, $J=7.5 \mathrm{~Hz}, \mathrm{H}-1 \mathrm{Glc}$ ), 3.38 (dd, $J=7.5$ and $9.0 \mathrm{~Hz}, \mathrm{H}-2 \mathrm{Glc}$ ), 3.49 (dd, $J=9.0$ and $9.0 \mathrm{~Hz}, \mathrm{H}-3 \mathrm{Glc}$ ), 3.28 (dd, $J=9.0$ and $9.0 \mathrm{~Hz}, \mathrm{H}-4 \mathrm{Glc}$ ), 3.26 (ddd, $J=2.5,4.5$ and $9.0 \mathrm{~Hz}, \mathrm{H}-5 \mathrm{Glc}$ ), 3.89 (dd, $J=4.5$ and $11.5 \mathrm{~Hz}, \mathrm{H}-6 \mathrm{a} \mathrm{Glc}$ ), 3.68 (dd, $J=2.5$ and $11.5 \mathrm{~Hz}, \mathrm{H}-6 \mathrm{~b}$ Glc). 5.22 (d, H-1 Rha), 3.94 (dd, H-2 Rha), 3.69 (dd, H-3 Rha), 3.42 (dd, H-4 Rha), 4.16 (m, H-5 Rha), 1.27 (d, H-6 Rha). For ${ }^{13} \mathrm{C}$ NMR see Table.

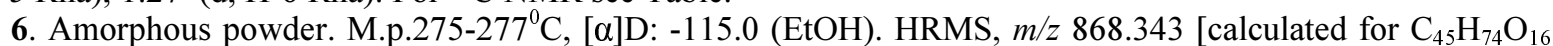
$\left.(\mathrm{M})^{+}\right] ; 722.4[\mathrm{M}-146]^{+} ; 576[\mathrm{M}-2 \times 146]^{+} ;{ }^{1} \mathrm{H}$ NMR (aglycon) $\delta 4.43(1 \mathrm{H}, \mathrm{m}, \mathrm{H}-16), 3.62(1 \mathrm{H}, \mathrm{m}, \mathrm{H}-3), 3.45(1 \mathrm{H}, \mathrm{m}$, H-26a), 3.34 (1H, m, H-26b), 1.02 (3H, s, Me-19), 0.83 (3H, s, Me-18), 0.98 (3H, d, H-21), 0.83(3H, d, Me-27). (sugars) $\delta 4.53$ (d, $J=7.4 \mathrm{~Hz}, \mathrm{H}-1 \mathrm{Glc}$ ), 3.42 (dd, $J=7.4$ and $9.0 \mathrm{~Hz}, \mathrm{H}-2 \mathrm{Glc}$ ), 3.61 (dd, $J=4.0$ and $9.0 \mathrm{~Hz}, \mathrm{H}-3 \mathrm{Glc}$ ), 3.55 (dd, $J=2.5$ and $4.0 \mathrm{~Hz}, \mathrm{H}-4 \mathrm{Glc}$ ), 3.35 (ddd, $J=2.5,2.5$ and $4.5 \mathrm{~Hz}, \mathrm{H}-5 \mathrm{Glc}$ ), 3.82 (dd, $J=4.5$ and $12.0 \mathrm{~Hz}, \mathrm{H}-6 \mathrm{a}$ Glc), 3.67 (dd, $J=2.5$ and 12.0 Hz, H-6b Glc); 4.87 (d, H-1Rha), 3.86 (dd, H-2 Rha), 3.65 (dd, H-3 Rha), 3.43 (dd, H4 Rha), 3.95 (m, H-5 Rha), 1.29 (d, H-6Rha); 5.23 (d, H-1 RhaI), 3.95 (dd, H-2 RhaI), 3.68 (dd, H-3 RhaI), 3.43 (dd, H-4 RhaI), 4.95 (m, H-5 RhaI), 1.28 (d, H-6 RhaI). For ${ }^{13} \mathrm{C}$ NMR see Table.

7. Amorphous powder. M.p.268-269 ${ }^{0}$, $[\alpha] \mathrm{D}$ : $-73.0(\mathrm{MeOH})$. HRMS, $m / z$ 870.576 [calculated for $\mathrm{C}_{45} \mathrm{H}_{76} \mathrm{O}_{16}$ $\left.(\mathrm{M})^{+}\right] ; 724.3[\mathrm{M}-146]^{+} ; 578.2[\mathrm{M}-2 \times 146]^{+} ;{ }^{1} \mathrm{H}$ NMR (aglycon) $\delta 4.43(1 \mathrm{H}, \mathrm{m}, \mathrm{H}-16), 3.62(1 \mathrm{H}, \mathrm{m}, \mathrm{H}-3), 3.45(1 \mathrm{H}$, m, H-26a), 3.34 (1H, m, H-26b), 0.89 (3H, s, Me-19), 0.82 (3H, s, Me-18), 1.00 (3H, d, H-21), 1.12 (3H, d, Me-27). (sugars) $\delta 4.53$ (d, $J=7.4 \mathrm{~Hz}, \mathrm{H}-1 \mathrm{Glc}$ ), 3.42 (dd, $J=7.4$ and $9.0 \mathrm{~Hz}, \mathrm{H}-2 \mathrm{Glc}$ ), 3.61 (dd, $J=4.0$ and 9.0 Hz, H-3 Glc), 
3.55 (dd, $J=2.5$ and $4.0 \mathrm{~Hz}, \mathrm{H}-4 \mathrm{Glc}$ ), 3.35 (ddd, $J=2.5,2.5$ and $4.5 \mathrm{~Hz}, \mathrm{H}-5 \mathrm{Glc}$ ), 3.82 (dd, $J=4.5$ and $12.0 \mathrm{~Hz}, \mathrm{H}-6 \mathrm{a}$ Glc), 3.67 (dd, $J=2.5$ and $12.0 \mathrm{~Hz}, \mathrm{H}-6 \mathrm{~b}$ Glc); 4.87 (d, H-1Rha), 3.86 (dd, H-2 Rha), 3.65 (dd, H-3 Rha), 3.43 (dd, H4 Rha), 3.95 (m, H-5 Rha), 1.29 (d, H-6Rha); 5.23 (d, H-1 RhaI), 3.95 (dd, H-2 RhaI), 3.68 (dd, H-3 RhaI), 3.43 (dd, H-4 RhaI), 4.95 (m, H-5 Rhal), 1.28 (d, H-6 RhaI). For ${ }^{13} \mathrm{C}$ NMR see Table.

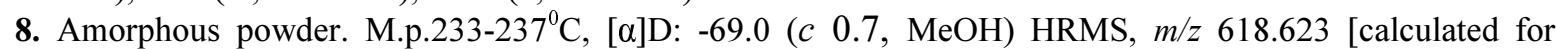
$\left.\mathrm{C}_{33} \mathrm{H}_{50} \mathrm{O}_{11}(\mathrm{M})^{+}\right] ; 472.241[\mathrm{M}-146]^{+} ;{ }^{1} \mathrm{H}$ NMR (aglycon) $6.91(1 \mathrm{H}, \mathrm{m}, \mathrm{H}-16), 3.69(1 \mathrm{H}, \mathrm{m}, \mathrm{H}-3), 0.95(3 \mathrm{H}, \mathrm{s}, \mathrm{Me}-19)$, 1.02 (3H, s, Me-18), 2.28 (3H, d, H-21). (sugars) 4.43 (d, J=7.5 Hz, H-1 Glc), 3.22 (dd, $J=7.5$ and 9.0 Hz, H-2 Glc), 3.49 (dd, $J=9.0$ and $9.0 \mathrm{~Hz}, \mathrm{H}-3 \mathrm{Glc}$ ), 3.56 (dd, $J=9.0$ and $9.0 \mathrm{~Hz}, \mathrm{H}-4 \mathrm{Glc}$ ), 3.35 (ddd, $J=2.5,4.5 \mathrm{and} 9.0 \mathrm{~Hz}, \mathrm{H}-5$ Glc), 3.82 (dd, $J=4.5$ and $11.5 \mathrm{~Hz}, \mathrm{H}-6 \mathrm{a} \mathrm{Glc}$ ), 3.69 (dd, $J=2.5$ and $11.5 \mathrm{~Hz}, \mathrm{H}-6 \mathrm{~b}$ Glc). 4.88 (d, H-1Rha), 3.87 (dd, H-2 Rha), 3.66 (dd, H-3 Rha), 3.43 (dd, H-4 Rha), 3.99 (m, H-5 Rha), 1.29 (d, H-6 Rha). For ${ }^{13}$ C NMR see Table.

\section{Conclusion}

One new cholestane glycoside, six steroidal glycosides of spirostane series and one pregnane glycoside have been isolated for the first time from the roots of Solanum melongena L. During the investigation their structures have been determined as 3-O- $\alpha$-L-rhamnopyranosyl- $(1 \rightarrow 4)-\beta$-D- glucopyranoside-(25R)-cholest-5-en, 22-one, 3 $\beta, 16 \beta, 26$ triol for compound 1, $(25 R)$-spirost-5-ene-3 $\beta$-ol - 3-O- $\alpha$-L-rhamnopyranosyl- $(1 \rightarrow 4)$ - $\beta$ - D-glucopyranoside for

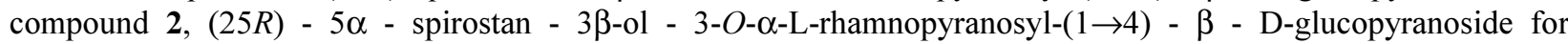
compound 3, (25R)-spirost- 5-ene-3 $\beta$-ol-3-O- $\alpha$-L-rhamnopyranosyl- $(1 \rightarrow 2)-\beta$-D-glucopyranoside for compound $\mathbf{4}$,

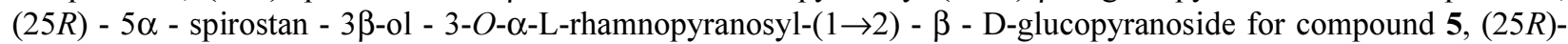

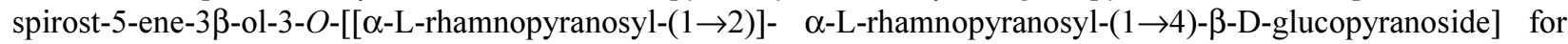

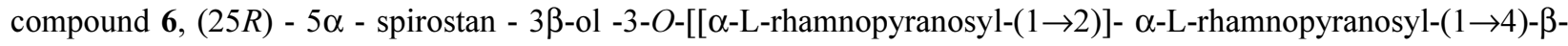
D-glucopyranoside] for compound 7 and 3-O- $\alpha$-L-rhamnopyranosyl - $(1 \rightarrow 4)-\beta$ - D - glucopyranoside - pregn - 5, 16 - dien - 20 - one, $3 \beta$-ol for compound 8. Compounds 2-8 are known steroidal glycosides and their physicochemical data coincide with literature ones.

\section{Acknowledgments}

The authors are grateful to Prof. Assunta Napolitana from the Department of Pharmaceutical Sciences, University of Salerno for MS measurements.

\section{References}

[1]. Ward M. Tingey. Glycoalcaloids as pest resistance factors. American Journal of Potato Research, 1984, V. 61, Nr 3 , p.157-167.

[2]. S. N. Alam, M. A. Rashid, F.M.A. Rouf, R.C. Jhala, J.R. Patel, S. Satpathy, T.M. Shivalingaswamy, S. Rail, I. Wahundeniya, A. Cork, C. Ammaranan and N.S. Talekar. Development of an Integrated Pest Menagement Strategy for Eggplant Fruit and Shoot Barer in South Asia. Technical Bulletin TB28, AVRDC, The World Vegetable Center, Shanhua, Taiwan, 2003, p.66.

[3]. National Plant Data Center, Baton Rouge, LA 70874-4490, USA.

[4]. Ikeda, T.; Ando, J.; Miyazono, A.; Zhu, X.-H.; Tsumagari, H.; Nohara, T.; Yokomizo, K.; Uyeda, M. Anti-herpes virusactivity of Solanum steroidal glycosides. Biological Pharmaceutical Bulletin 2000, V.23, p.363-364.

[5]. Grünweller S., Schröder E., Kesselmeier J. Biological activities of furostanol saponins from Nicotiana tabacum. Phytochemistry, 1990, V. 29, p. 2485-2490.

[6]. Mimaki Y., Kuroda M., Kameyama A., Yokosuka A., Sashida Y. Steroidal saponins from the rhizomes of Hosta sieboldii and their cytostatic activity on HL-60 cells. Phytochemistry, 1998, V.48, p. 1361-1369.

[7]. Pulok K. Mukherjee. Plant products with hypocholesterolemic potentials. Advances in Food and Nutrition Research, 2003, V.47, p.277-338.

[8]. Kintia, P. K. and Shvets, S. A. Melongoside L and melongoside M, steroidal saponins from Solanum melongena seeds. Phytochemistry, 1985, V.24, p.197-198.

[9]. Kintia, P. K. and Shvets, S. A. Melongosides N, O and P: steroidal saponins from seeds of Solanum melongena. Phytochemistry, 1985, V.24, p.1567-1569.

[10]. Agrawal P.K., Jain D.C., Gufta R.K., Thakuv R.S. Carbon-13 NMR spectroscopy of steroidal sapogenins and steroidal saponins. Phytochemistry, 1985, 24, 2479-2496.

[11]. Biao Yu, Guowen Xing, Yongzheng Hui and Xiuwen Han. Lipase-catalyzed regioselective acylation of diosgenyl saponins. Tetrahedron Letters, 2001, V. 42, p. 5513-5516.

[12]. Wang Y., Kazuhiro O., Ryoji K., Kazuo Y. Steroidal saponins from fruits of Tribulus terrestris. Phytochemistry, 1996, V. 42(5), p. 1417-1422.

[13]. Lunga, I., Kintia, P., Shvets, S., Bassarello, C., Pizza, C. and Piacente, S. Three spirostanol glycosides from the seeds of Hyoscyamus niger L. Chemistry Journal of Moldova, 2006, V.1, N.1, p.123-127.

[14]. Ikeda T., Tsumagari H., Honbu T. and Nohara T. Cytotoxic Activity of Steroidal Glycosides from Solanum Plants. Biol. Pharm. Bull., 2003, V.26(8), p.1198-1201.

[15]. Shvets, S.A.; Kintia, P.K.; Shashkov, A.S. Melangoside $G_{1}$ and dioscin from the seeds of eggplant. VIII International conference of chemistry and biochemistry of carbohydrates. Tbilisi, Georgia, 1987, p.75.

[16]. Jun Yin, Kyoji Kouda, Yasuhiro Tezuka, Quan Le Tran, Tatsuro Miyahara, Yingjie Chen and Shigetoshi Kadota. Steroidal Glycosides from the Rhizomes of Dioscorea spongios. J. Nat. Prod. 2003, V.66, p.646-650. 